\title{
Impacts of Maternal Genotype on Pecan Seedling Performance in an Alkaline, Saline-sodic Soil
}

\author{
Cyrus A. Smith, James L. Walworth, and Mary J. Comeau \\ Department of Environmental Science, University of Arizona, 429 Shantz \\ Building \#38, Tucson, AZ 85721
}

\author{
Richard J. Heerema \\ Department of Plant and Environmental Sciences, New Mexico State \\ University, Las Cruces, NM 88003
}

Joshua D. Sherman

Arizona Cooperative Extension, University of Arizona, Willcox, AZ 85643

\section{Randall Norton \\ Safford Agricultural Center, University of Arizona, Safford, AZ 85546}

Additional index words. pecan, salinity, rootstock, growth rate, salt injury

\begin{abstract}
A field study was conducted to evaluate tolerance of pecan rootstocks to soil salinity and sodicity. Seven cultivars-Elliott, Giles, Ideal, Peruque, Riverside, 'Shoshoni, and VC1-68 - were selected from a range of geographic regions of origin. The soil of the experimental plot was a poorly drained, saline-sodic Pima silty clay variant. The irrigation water was a moderately saline mix of Gila River and local groundwater with an electrical conductivity of $2.8 \mathrm{dS} \cdot \mathrm{m}^{-1}$, containing primarily ions of $\mathrm{Na}$ and $\mathrm{Cl}$. Eighty seeds of each cultivar were planted in a greenhouse in late Feb. 2016; 48 seedlings of each cultivar were transplanted into field plots in Feb. 2017. Half the trees received a soil-based application of $\mathrm{Zn}$-ethylenediaminetetraacetic acid (EDTA) at planting. The trees were observed and rated for both vigor and resistance to salt injury on seven separate occasions. Trunk diameter was measured each dormant season. Leaf samples were collected on 9 Oct. 2019 and 6 Oct. 2020, and were analyzed for nutrient content. Zn-EDTA was not found to have a significant effect on growth, vigor, or resistance to salt injury. 'Elliott' seedlings exhibited greater tolerance for the alkaline, saline-sodic soil conditions than other cultivars. 'Giles' and 'Peruque' were most severely affected. Resistance to salt injury (ranging from marginal leaf burn to necrosis of entire leaf), vigor, and growth correlated more strongly with foliar concentrations of $\mathrm{Na}$ than $\mathrm{Cl}$ or $\mathrm{K}$ during 2019. Vigor and growth were not significantly correlated with foliar $\mathrm{Na}, \mathrm{Cl}$, or $\mathrm{K}$ concentrations in 2020 . The foliar $\mathrm{K}: \mathrm{Na}$ ratio had a nearly equal correlation with resistance to salt injury and a greater correlation with growth than that of $\mathrm{Na}$ alone in 2019. However, although the correlation of the $\mathrm{K}$ : Na ratio with vigor was stronger than that of $\mathrm{Cl}$ or $\mathrm{K}$, $\mathrm{Na}$ had the strongest correlation with vigor in 2019 . In 2020 , the only significant correlation of growth and vigor was with the $\mathrm{K}$ : Na ratio. The strongest correlation with resistance to salt injury in 2020 was with foliar Na concentration.
\end{abstract}

Soil conditions, including sodicity, salinity, and poor drainage, limit distribution of pecan [Carya illinoinensis (Wangenh.) K. Koch] acreage in the southwestern United

Received for publication 13 Apr. 2021. Accepted for publication 2 June 2021.

Published online 20 July 2021.

We thank Farmers Investment Co. (FICO), Linwood Nursery (La Grange, CA), the U.S. Department of Agriculture (grant no. 2016-51181-25408) Coordinated Development Of Genetic Tools For Pecan for their support of this research. We also thank Civano Nursery (Tucson, AZ) for growing the seedlings.

J.L.W. is the corresponding author. E-mail: walworth@ag.arizona.edu.

This is an open access article distributed under the CC BY-NC-ND license (https://creativecommons. org/licenses/by-nc-nd/4.0/).
States. Multiple aspects of plant physiology and metabolism are affected by salinity stress (Tuteja, 2007). Low water potentials associated with high salt content in the soil solution make it more difficult for plant roots to acquire water. Sodic soils (soils with an exchangeable sodium percentage greater than $15 \%)$ are associated with unstable soil structure, poor drainage, and salt accumulation (Sumner, 1993). High levels of $\mathrm{Na}$ impact K uptake negatively in plants, causing a disturbance in the function of certain enzymes and stomata as well as in the osmotic balance (Tuteja, 2007).

Cell injury caused by ion excess in the leaves reduces growth and can lead to leaf senescence and plant mortality. Plants have been reported to have two phases of response to salinity stress: 1) young leaf growth is inhibited by osmotic stress and 2) senescence of mature leaves is accelerated by an ionic phase in which toxic levels of salts accumulate (Munns and Tester, 2008). Rajendran et al. (2009) suggested that the three main components of salinity stress tolerance in cereals are $\mathrm{Na}$ exclusion, $\mathrm{Na}$ tolerance in plant tissues, and osmotic stress tolerance. Munns and Tester (2008) described these mechanisms more broadly as $\mathrm{Na}$ or $\mathrm{Cl}$ exclusion, tolerance to accumulated $\mathrm{Na}$ or $\mathrm{Cl}$, and tolerance to osmotic stress, and speculated that because plants use $\mathrm{Na}$ and $\mathrm{Cl}$ to maintain turgor pressure in leaves, the plant may need to develop a balance between these ions to avoid ion toxicity.

It is unclear which of the ions in saline water or soil cause salt injury in pecans. Faruque (1968) treated 'Riverside' pecan seedlings growing in sand culture with various salt solutions, expressed in terms of osmotic pressure. The results of that study determined that salt injury to leaves was caused by $\mathrm{Cl}$ rather than $\mathrm{Na}$. Seedlings treated with $\mathrm{NaCl}$ solutions began to exhibit significant injuries (measured by percent necrosis of leaves) when growing in a $0.15-\mathrm{MPa}$ osmotic pressure solution, and a $0.30-\mathrm{MPa}$ solution resulted in death. Seedlings treated with $\mathrm{CaCl}_{2}$ began to show significant injuries at $0.20 \mathrm{MPa}$, but no injury was caused by $\mathrm{Na}_{2} \mathrm{SO}_{4}$ solutions with an osmotic pressure as great as $0.30 \mathrm{MPa}$, implicating $\mathrm{Cl}$ and not $\mathrm{Na}$ as the causal agent. Necrosis occurred in leaves of seedlings with a whole plant tissue content of $5959 \mathrm{mg} \cdot \mathrm{kg}^{-1} \mathrm{Cl}$ when trees were treated with either $\mathrm{NaCl}$ or $\mathrm{CaCl}_{2}$. Similarly, Harper (1946) found that leaf content of 6000 $\mathrm{mg} \cdot \mathrm{kg}^{-1} \mathrm{Cl}$ caused severe damage to pecans. In contrast, Miyamoto et al. (1985) reported that $\mathrm{Na}$ content, but not $\mathrm{Cl}$ content, in pecan leaves demonstrated a strong negative correlation with leaf, stem, and root weight.

Although few studies have investigated pecan cultivar sensitivity to salts, Hanna (1972) found that seedlings produced by hand pollination of identical parentage exhibited a wide range of patterns of $\mathrm{Cl}$ absorption. Miyamoto et al. (1985) reported that 'Riverside' seedlings absorbed less $\mathrm{Na}$ and showed less salt damage than 'Apache' and 'Burkett', the two other cultivars tested.

The foliar K:Na ratio has been found to be a factor in salinity tolerance. Gorham (1990) reported that salinity tolerance in Aegilops (goatgrass) species was related to the ability to maintain high leaf $\mathrm{K}: \mathrm{Na}$ ratios. Munns and Tester (2008) indicated that foliar $\mathrm{K}: \mathrm{Na}$ ratios were a function of ion transporter genes and that salinity tolerance in plants may be related to increased leaf tissue $\mathrm{K}: \mathrm{Na}$ ratios. Almeida et al. (2017) noted that $\mathrm{Na}$ inhibits $\mathrm{K}$ uptake by cells and likely inhibits $\mathrm{K}$ transporters. Wakeel (2013) pointed out that an optimal $\mathrm{K}: \mathrm{Na}$ ratio is essential for the activation of enzymatic reactions in the cytoplasm required for maintaining plant growth.

Soil physical properties can affect salt accumulation in the soil profile. Clayey soils with low permeability and greater specific surface area tend to accumulate more salts 
than porous, well-drained soils (Warrence et al., 2002). Irrigated pecan orchards with low permeability (e.g., poorly drained alluvial soils) may exhibit salt accumulation (Miyamoto and Storey, 1995). Miyamoto et al. (1986) noted that 'Western' scions grafted to 'Riverside' rootstock grown in soils with a high clay content (silty clays and silty clay loams) were stunted and had a smaller trunk diameter than trees planted in coarser textured (loam) soil. Greater salt accumulation occurred in the clayey soils. In soils with a saturated paste extract electrical conductivity $\left(\mathrm{EC}_{\mathrm{e}}\right)$ in the upper $30 \mathrm{~cm}$ greater than $2.0 \mathrm{dS} \cdot \mathrm{m}^{-1}$, trunk diameter was reduced. Branch dieback occurred when $\mathrm{EC}_{\mathrm{e}}$ exceeded $6.0 \mathrm{dS} \cdot \mathrm{m}^{-1}$.

A major source of soil salts in irrigated systems is irrigation water. Deb et al. (2013) found that use of irrigation water with $\mathrm{EC}_{\text {irr }}$ (irrigation water electrical conductivity) between 1.4 and $3.5 \mathrm{dS} \cdot \mathrm{m}^{-1}$ resulted in soil $\mathrm{EC}_{1: 1}$ (soil salinity of a $1: 1 \mathrm{soil} /$ water extract) of between 0.89 and $2.71 \mathrm{dS} \cdot \mathrm{m}^{-1}$. In 1-year-old 'Western' grafted to 'Riverside' rootstock, this level of salinity resulted in budbreak delay and inhibition, as well as reduced seedling growth rate. Visible symptoms of salt injury occurred at an $\mathrm{EC}_{\text {irr }}$ of $3.5 \mathrm{dS} \cdot \mathrm{m}^{-1}$. Seedlings did not survive the 2-year test period when $\mathrm{EC}_{\text {irr }}$ levels were $5.5 \mathrm{dS} \cdot \mathrm{m}^{-1}$ or more.

Plant $\mathrm{Zn}$ content has been reported to be related to salinity tolerance (Cakmak, 2000). Zinc promotes the synthesis and activity of antioxidative enzymes that can help prevent damage from oxidative stress factors, including salinity (Cakmak, 2000). Therefore, improving the $\mathrm{Zn}$ nutritional status of plants grown in arid and semiarid regions with saline soils may be important for not only preventing $\mathrm{Zn}$ deficiency, but also for protecting plants against the damage caused by excess salinity. Norvell and Welch (1993) suggested that increased $\mathrm{Zn}$ may reduce plant accumulation of $\mathrm{Na}$. Zinc has been shown to increase salinity tolerance in chickpea (Cicer arietinum L.), as evidenced by reduced levels of $\mathrm{Na}$ uptake and elevated levels of $\mathrm{K}$ in shoots (Saxena and Rewari, 1990). In soybeans (Glycine max L.) grown in two saline soils, one with primarily chloride salts, the other with sulfate salts, the uptake of $\mathrm{Zn}$ was suppressed in proportion to the salinity of the soil (Gupta and Gupta, 1984).

Long-term drought and expansion of pecan acreage in the semiarid southwestern United States have increased use of low-quality irrigation water in pecan production. This has accentuated the need for rootstocks that are tolerant of sodic and saline soil conditions. To this end, we conducted a field study to evaluate the effect of maternal genotype on pecan seedling tolerance to such conditions, and to evaluate the effect of the application of Zn-ethylenediaminetetraacetic acid (EDTA) on rootstock performance. We selected openpollinated seeds from several cultivars originating from environmentally diverse parts of the pecan native range. We expected that seedlings with genetic origins that lie in lower precipitation regions where saline and sodic soils are more common would be more tolerant of
Table 1 . Soil analysis from samples taken on 25 July $2018 .^{\text {z }}$

\begin{tabular}{|c|c|c|c|c|c|}
\hline \multirow[b]{2}{*}{ Method } & \multirow[b]{2}{*}{ Test } & \multirow[b]{2}{*}{ Units } & \multicolumn{3}{|c|}{ Soil depth $(\mathrm{cm})$} \\
\hline & & & $0-15$ & $15-30$ & $30-60$ \\
\hline$\overline{1: 1}$ & $\mathrm{pH}$ & SU & 8.5 & 8.5 & 8.8 \\
\hline $1: 1$ & $\mathrm{EC}_{1: 1}$ & $\mathrm{dS} \cdot \mathrm{m}^{-1}$ & 3.4 & 2.8 & 2.1 \\
\hline Calculated & $\mathrm{EC}_{\mathrm{e}}$ & $\mathrm{dS} \cdot \mathrm{m}^{-1}$ & 7.5 & 6.5 & 5.2 \\
\hline NH4OAc (pH 8.5) & $\mathrm{Ca}$ & $\mathrm{mg} \cdot \mathrm{kg}^{-1}$ & 4,050 & 4,125 & 3,592 \\
\hline NH4OAc (pH 8.5) & $\mathrm{Mg}$ & $\mathrm{mg} \cdot \mathrm{kg}^{-1}$ & 510 & 563 & 514 \\
\hline NH4OAc (pH 8.5) & $\mathrm{Na}$ & $\mathrm{mg} \cdot \mathrm{kg}^{-1}$ & 4,408 & 3,433 & 2,700 \\
\hline NH4OAc (pH 8.5) & $\mathrm{K}$ & $\mathrm{mg} \cdot \mathrm{kg}^{-1}$ & 653 & 618 & 489 \\
\hline DTPA & $\mathrm{Zn}$ & $\mathrm{mg} \cdot \mathrm{kg}^{-1}$ & 1.9 & 2.1 & 2.0 \\
\hline DTPA & $\mathrm{Fe}$ & $\mathrm{mg} \cdot \mathrm{kg}^{-1}$ & 4.0 & 3.8 & 4.2 \\
\hline DTPA & $\mathrm{Mn}$ & $\mathrm{mg} \cdot \mathrm{kg}^{-1}$ & 4.7 & 4.2 & 4.1 \\
\hline DTPA & $\mathrm{Cu}$ & $\mathrm{mg} \cdot \mathrm{kg}^{-1}$ & 20.7 & 22.7 & 18.1 \\
\hline DTPA & $\mathrm{Ni}$ & $\mathrm{mg} \cdot \mathrm{kg}^{-1}$ & 0.1 & 0.1 & 0.1 \\
\hline $\mathrm{Cd}$ reduction & $\mathrm{NO}_{3}$ & $\mathrm{mg} \cdot \mathrm{kg}^{-1}$ & 24.1 & 22.9 & 17.5 \\
\hline Olsen & $\mathrm{PO}_{4}$ & $\mathrm{mg} \cdot \mathrm{kg}^{-1}$ & 8.1 & 7.4 & 5.6 \\
\hline Hot water & $\mathrm{SO}_{4}$ & $\mathrm{mg} \cdot \mathrm{kg}^{-1}$ & 190 & 155 & 107 \\
\hline Hot water & B & $\mathrm{mg} \cdot \mathrm{kg}^{-1}$ & 3.2 & 2.6 & 2.3 \\
\hline Acid test & Free lime & - & High & High & High \\
\hline Calculated & ESP & $\%$ & 42.0 & 35.5 & 32.2 \\
\hline Calculated & CEC & meq/100 g & 45.3 & 41.8 & 35.2 \\
\hline
\end{tabular}

${ }^{\mathrm{z}}$ One sample was taken from each of 12 rows. Values at each depth are averaged from all samples. $\mathrm{EC}_{\mathrm{e}}$ was calculated from $\mathrm{EC}_{1: 1}$ using the equation from Fig. 1 of Zhang et al. (2005).

$\mathrm{DTPA}=$ diethylenetriamine pentaacetate; $\mathrm{EC}=$ electrical conductivity; $\mathrm{ECe}=$ electrical conductivity of saturated paste extract; ESP = exchangeable sodium percentage; $\mathrm{CEC}=$ cation exchange capacity. these soil conditions than those with genetic origins that lie in higher precipitation areas.

\section{Materials and Methods}

A field experiment was conducted at the University of Arizona Safford Agricultural Center in Safford, AZ (lat. $32^{\circ} 48^{\prime} 57^{\prime \prime} \mathrm{N}$, long. $\left.109^{\circ} 40^{\prime} 48^{\prime \prime} \mathrm{W}\right)$. This location receives an average annual precipitation of $\approx 24.6 \mathrm{~cm}$ (Your Weather Service, 2021). Soil samples were collected on 25 July 2018. The soil is a salinesodic alluvial Pima silty clay variant [Coarseloamy, mixed (calcareous), thermic Typic
Torrifluvents] (Post et al., 1977) with an $\mathrm{EC}_{1: 1}$ of $3.4 \mathrm{dS} \cdot \mathrm{m}^{-1}$ at a depth of 0 to $15 \mathrm{~cm}, 2.8$ $\mathrm{dS} \cdot \mathrm{m}^{-1}$ at a depth of 15 to 30 , and $2.1 \mathrm{dS} \cdot \mathrm{m}^{-1}$ at a depth of 30 to $60 \mathrm{~cm}$ (Table 1). The plots were flood irrigated with a blend of Gila River water and groundwater with an EC of 2.8 $\mathrm{dS} \cdot \mathrm{m}^{-1}$ at a rate of 11 to $15 \mathrm{~cm}$ per irrigation event, with $\approx 10$ events per year. The dominant irrigation water ions are $\mathrm{Na}$ and $\mathrm{Cl}$.

In an attempt to maximize genetic variability with respect to salinity tolerance, seven pecan rootstock cultivars were selected based on probable location of origin (Grauke and Thompson, 2019) (Table 2). 'Elliott' is a
Table 2. Origin descriptions of selected pecan cultivars.

\begin{tabular}{ll}
\hline Cultivar & \multicolumn{1}{c}{ Description $^{\text {z }}$} \\
\hline Elliott & A seedling selected from Milton, FL, in 1912; probably from trees of Mexican origin \\
Giles & A native seedling from near Chetopa, KS, 1927 \\
Ideal & A seedling selection from San Saba, TX, selected about 1925 \\
Peruque & A native seedling from St. Charles, MO, in 1918 \\
Riverside & A seedling selected in Big Valley, TX \\
Shoshoni & USDA-ARS cross of 'Odom' (seedling from MS) $\times$ 'Evers' (seedling from Arlington, \\
& TX) made in Brownwood, TX, in 1944; released in 1972 \\
VC1-68 & A seedling of unknown origin selected in Phoenix, AZ, in 1968
\end{tabular}

${ }^{\mathrm{z} B a s e d}$ on Grauke and Thompson (2019).

USDA-ARS = U.S. Department of Agriculture-Agricultural Research Service.

Table 3. Mean resistance to salt injury ratings of pecan rootstocks from seven seed source cultivars on all observation dates. ${ }^{\mathrm{z}}$

\begin{tabular}{lccccccc}
\hline & \multicolumn{7}{c}{ Observation date } \\
\cline { 2 - 7 } Seed source & 28 Sept. & 18 June & 12 Sept. & 20 June & 9 Oct. & 26 June & 6 Oct. \\
cultivar & 2017 & 2018 & 2018 & 2019 & 2019 & 2020 & 2020 \\
\hline Elliott & $2.8 \mathrm{ab}$ & $3.9 \mathrm{a}$ & $3.6 \mathrm{a}$ & $4.4 \mathrm{ab}$ & $3.8 \mathrm{a}$ & $3.9 \mathrm{bc}$ & $3.8 \mathrm{a}$ \\
Giles & $1.8 \mathrm{~d}$ & $3.7 \mathrm{abc}$ & $2.8 \mathrm{bc}$ & $4.2 \mathrm{abc}$ & $2.6 \mathrm{~b}$ & $4.0 \mathrm{abc}$ & $3.1 \mathrm{bc}$ \\
Ideal & $2.5 \mathrm{bc}$ & $4.1 \mathrm{a}$ & $3.0 \mathrm{~b}$ & $4.5 \mathrm{a}$ & $2.9 \mathrm{~b}$ & $4.1 \mathrm{ab}$ & $3.1 \mathrm{c}$ \\
Peruque & $1.8 \mathrm{~d}$ & $3.2 \mathrm{c}$ & $2.2 \mathrm{~d}$ & $3.9 \mathrm{c}$ & $1.7 \mathrm{c}$ & $3.5 \mathrm{c}$ & $2.3 \mathrm{~d}$ \\
Riverside & $2.9 \mathrm{a}$ & $4.0 \mathrm{a}$ & $2.9 \mathrm{~b}$ & $4.4 \mathrm{ab}$ & $2.7 \mathrm{~b}$ & $3.9 \mathrm{bc}$ & $3.6 \mathrm{ab}$ \\
Shoshoni & $2.4 \mathrm{c}$ & $3.7 \mathrm{ab}$ & $2.5 \mathrm{~cd}$ & $4.4 \mathrm{ab}$ & $2.8 \mathrm{~b}$ & $4.4 \mathrm{a}$ & $2.7 \mathrm{~cd}$ \\
VC1-68 & $2.5 \mathrm{abc}$ & $3.2 \mathrm{bc}$ & $2.9 \mathrm{bc}$ & $4.1 \mathrm{bc}$ & $2.8 \mathrm{~b}$ & $3.8 \mathrm{bc}$ & $3.0 \mathrm{c}$ \\
\hline
\end{tabular}

${ }^{\mathrm{z}} \mathrm{A}$ rating of 5 represents the most resistance to salt injury; a rating of 1 represents the least. Values in each column that do not share the same letter are statistically different. 
Table 4. Mean vigor ratings of pecan rootstocks from seven seed source cultivars on all observation dates. $^{\mathrm{z}}$

\begin{tabular}{lcccccc}
\hline & \multicolumn{7}{c}{ Observation date } \\
\cline { 2 - 7 } Seed source & 18 June & $12 \mathrm{Sept}$ & $20 \mathrm{June}$ & 9 Oct. & 26 June & 6 Oct. \\
cultivar & 2018 & 2018 & 2019 & 2019 & 2020 & 2020 \\
\hline Elliott & $3.5 \mathrm{a}$ & $3.5 \mathrm{a}$ & $3.6 \mathrm{a}$ & $3.5 \mathrm{a}$ & $4.0 \mathrm{a}$ & $4.0 \mathrm{a}$ \\
Giles & $3.1 \mathrm{ab}$ & $2.5 \mathrm{~cd}$ & $3.1 \mathrm{~b}$ & $2.3 \mathrm{bc}$ & $3.0 \mathrm{de}$ & $2.8 \mathrm{~cd}$ \\
Ideal & $3.4 \mathrm{a}$ & $3.1 \mathrm{~b}$ & $3.2 \mathrm{~b}$ & $2.5 \mathrm{bc}$ & $3.6 \mathrm{bc}$ & $3.4 \mathrm{~b}$ \\
Peruque & $2.7 \mathrm{~b}$ & $2.3 \mathrm{~d}$ & $2.6 \mathrm{c}$ & $1.5 \mathrm{~d}$ & $2.6 \mathrm{e}$ & $2.3 \mathrm{~d}$ \\
Riverside & $3.1 \mathrm{ab}$ & $2.8 \mathrm{bc}$ & $3.0 \mathrm{~b}$ & $2.7 \mathrm{~b}$ & $3.2 \mathrm{~cd}$ & $3.4 \mathrm{bc}$ \\
Shoshoni & $3.4 \mathrm{a}$ & $2.8 \mathrm{bc}$ & $3.0 \mathrm{~b}$ & $2.2 \mathrm{c}$ & $3.7 \mathrm{ab}$ & $3.4 \mathrm{bc}$ \\
VC1-68 & $3.1 \mathrm{ab}$ & $3.2 \mathrm{ab}$ & $3.3 \mathrm{ab}$ & $2.5 \mathrm{bc}$ & $3.5 \mathrm{abcd}$ & $3.3 \mathrm{bc}$ \\
\hline
\end{tabular}

${ }^{\mathrm{z}} \mathrm{A}$ rating of 5 reflects healthy foliage and growth; a rating of 1 indicates the tree was alive but had very little or no green foliage or recent growth. Values in each column that do not share the same letter are statistically different.

commonly used rootstock in the southeastern United States; 'Peruque' and 'Giles' are common in midwestern states; 'Riverside', in the southwest, and 'VC1-68', in the West (Grauke, 2010). Eighty seeds of each of seven cultivars were planted in a greenhouse in late Feb. 2016. 'Riverside' and 'Ideal' seeds were collected from Farmers Investment Co. (Sahuarita, AZ) orchards in San Simon, AZ. The other five cultivars came from Linwood Nursery (La Grange, CA).

Forty-eight seedlings of each cultivar were transplanted into the field plots on 27 Feb. 2017. Seedlings of the seven pecan cultivars were arranged in a split-plot design with 12 replications. Each plot contained four trees, spaced $213 \mathrm{~cm}$ between trees and $6 \mathrm{~m}$ between rows. Main plots were cultivar, and
Table 5. Linear regression coefficients of determination between visual resistance to salt injury and plant vigor ratings by date.

\begin{tabular}{lc}
\hline Date & $r^{2}$ \\
\hline 18 June 2018 & 0.016 \\
12 Sept. 2018 & 0.358 \\
20 June 2019 & 0.122 \\
9 Oct. 2019 & 0.546 \\
26 June 2020 & 0.090 \\
6 Oct. 2020 & 0.217 \\
\hline
\end{tabular}

ratings were based on overall appearance of foliage (other than salt injury), size of leaves, and amount of recent growth. A rating of 5 reflected healthy foliage and growth, and a rating of 1 indicated the tree was alive but had very little or no green foliage or recent growth. Trunk diameters were measured 7 $\mathrm{cm}$ above the soil surface by electronic caliper in each dormant season. Annual tree growth was determined by comparing annual dormant season trunk caliper measurements.

Leaf samples were collected from each living tree that had enough leaf tissue to collect on 9 Oct. 2019. As a result of the severity of salt injury and size of some seedlings, standard pecan leaf-sampling protocols (Heerema, 2013) could not be followed. Although pecan leaf samples are usually collected in late July to early August, we waited until closer to the end of the growing season (October) to avoid defoliation injury to smaller plants. Some collected leaves had necrotic lesions, and leaf position on the tree

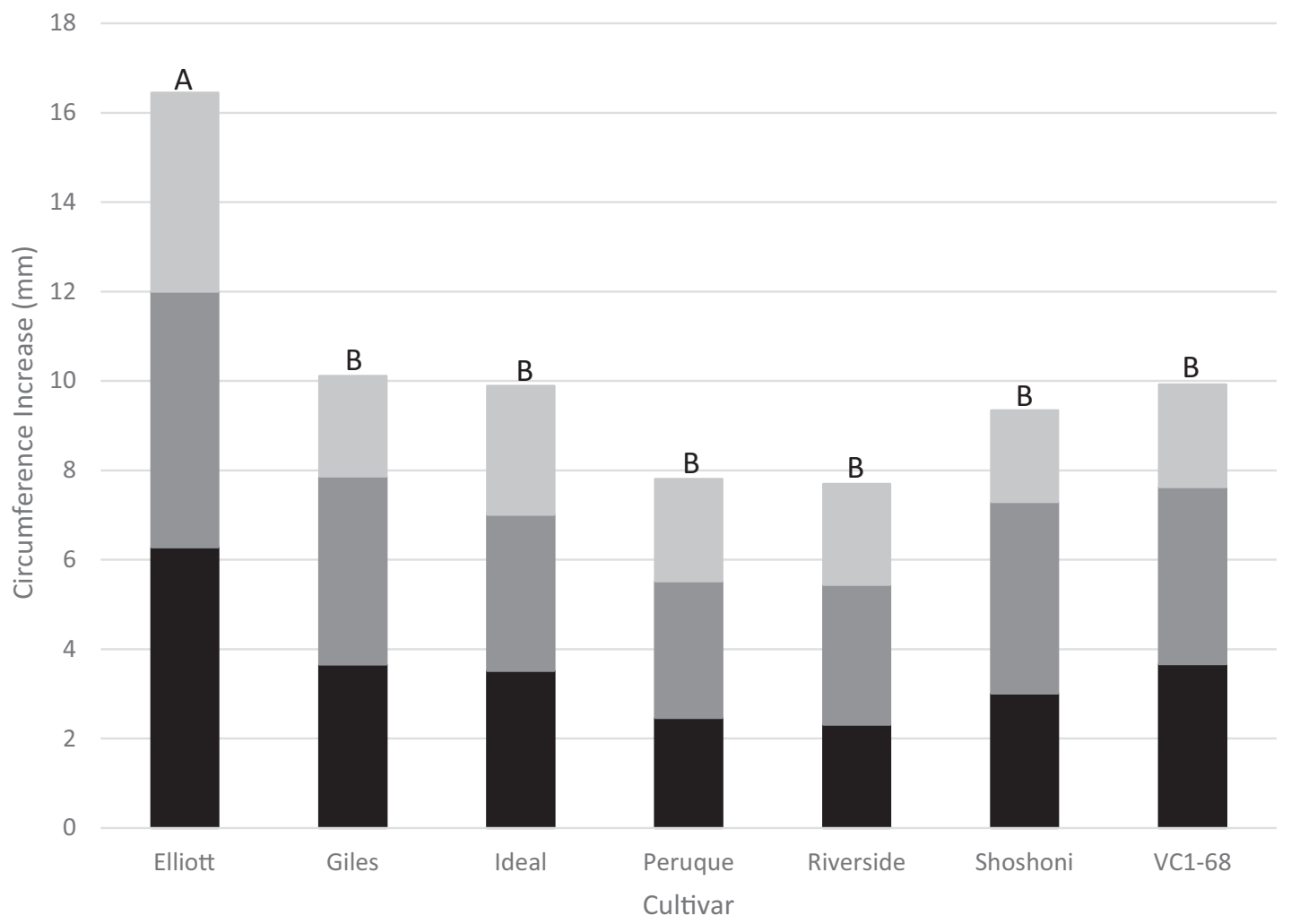

Fig. 1. Pecan tree growth rates determined from dormant season trunk caliper measurements. Annual growth is represented by various shades in each bar, and total bar height reflects cumulative growth. Columns that do not share the same letter have statistically different overall circumference increases. 

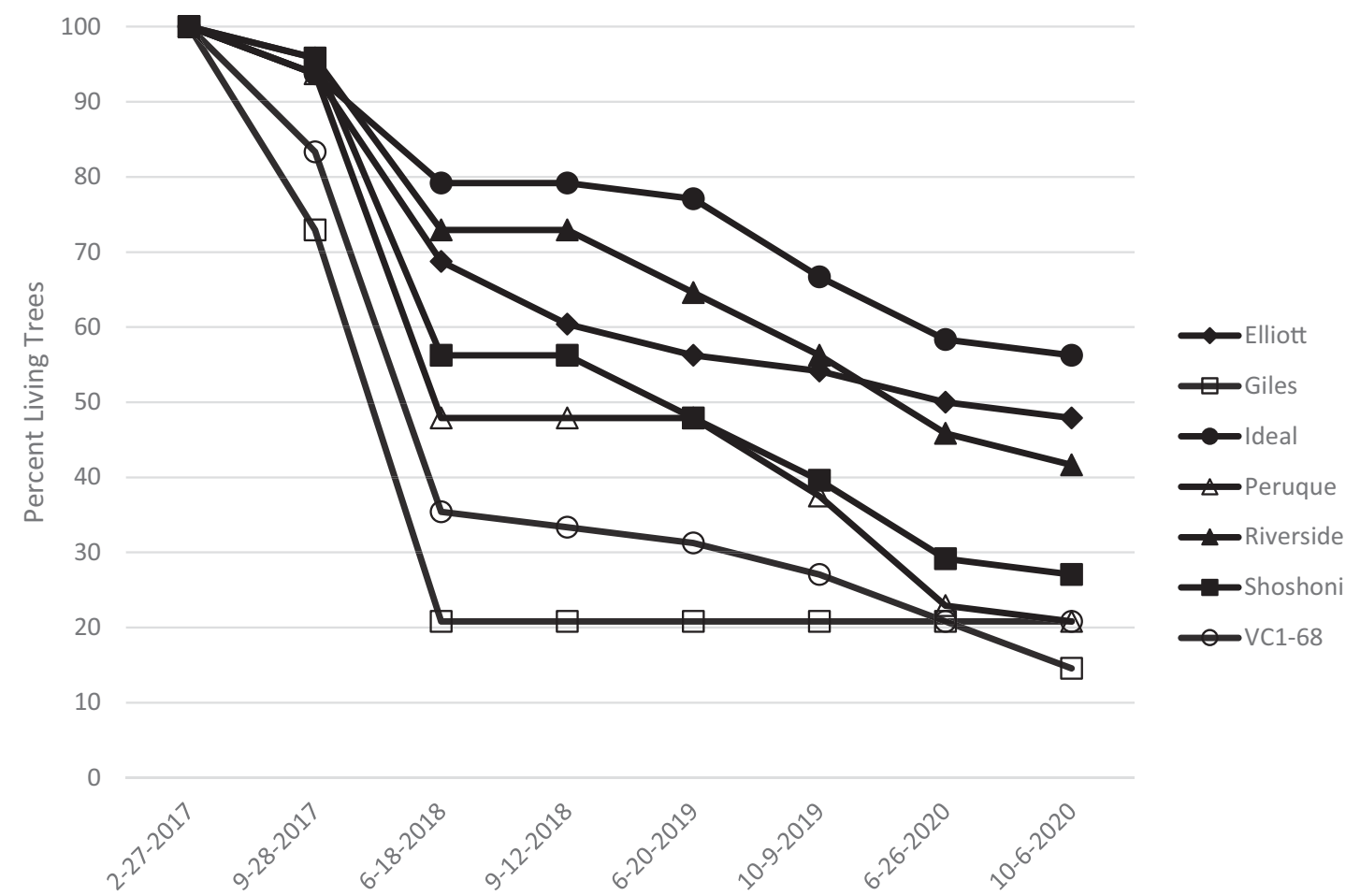

Planting and Observation Dates

Fig. 2. Rates of survival for all seven pecan cultivars throughout the study. Tree mortality was determined on each observation date. The planting date of 27 Feb. 2017 is included.

was ignored (i.e., leaves were collected from wherever on the seedling they were present). Composite samples were created for each cultivar by combining samples from individual trees to accumulate enough tissue for analysis. In 2019 and 2020, the living trees were separated into four groups, dependent on the number and location of living trees, by combining trees from separate replications. Four composite samples were derived for each cultivar except for 'Peruque', for which only two composite samples could be created. Some composite samples from 2019 contained trees that were either no longer alive or had too few leaves to be sampled in 2020 . This resulted in 'VC1-68' and 'Giles' having three composite samples in 2020, whereas in 2019 each of these cultivars had four composite samples. The leaflets were placed in a $65^{\circ} \mathrm{C}$ oven for $48 \mathrm{~h}$, then ground using a cyclone mill (UDY Corporation, Fort Collins, $\mathrm{CO}$ ). The samples were analyzed for complete nutrient content (Brookside Laboratories, Inc. New Bremen, OH).

JMP software (JMP 16.0; SAS Institute, Cary, NC) was used to perform analysis of variance. Connecting letters reports to show differences in means of data in figures and tables were obtained using the each pair Student's $t$ test. Microsoft Excel (Office 2016; Microsoft Corporation, Redmond, WA) was used for linear and nonlinear regressions.

\section{Results}

Application of Zn-EDTA at planting did not have a significant effect on any of the measurements. Therefore, all presented statistical analyses result from grouping those trees that did and did not receive $\mathrm{Zn}$ (i.e., main plots only). Ratings for vigor and resistance to salt injury describe conditions of surviving trees and are independent of the level of mortality among seedlings.

On 28 Sept. 2017 'Elliott' and 'Riverside' exhibited the greatest resistance to salt injury (Table 3). 'VC1-68', 'Ideal', and 'Shoshoni' were intermediate, and the least resistance to salt injury was observed in 'Peruque' and 'Giles'. Differences were less distinct in June 2018. 'Elliott' displayed the most resistance to salt injury late in the 2018 season. The ratings for 'Peruque' for resistance to salt injury were consistently among the lowest throughout 2018. Similar to 2018, differences in June 2019 were smaller than later season resistance to salt injury ratings. In late 2019, 'Elliott' showed significantly greater resistance to salt injury than all other seed source cultivars, repeating the pattern of 2018. 'Ideal', 'Riverside', 'Shoshoni', 'VC1-68', and 'Giles' were intermediate, and 'Peruque' had the least resistance to salt injury. Early in 2020, the most resistance to salt injury was seen in 'Ideal', 'Shoshoni', and 'Giles'. Late in 2020, 'Elliott' and 'Riverside' showed the most resistance to salt injury, whereas 'Peruque' and 'Shoshoni' were most affected.

Vigor ratings reflect general observable plant health and growth of surviving trees but do not consider leaf salt injury symptoms. Very little statistical difference in vigor was seen early in 2018 (Table 4). 'Elliott' and 'VC1-68' had the highest vigor ratings late in the 2018 season; 'Peruque' and 'Giles' were the least vigorous. 'Elliott' and 'VC1-68' continued to exhibit the highest ratings in June 2019, and 'Peruque' was least vigorous. 'Elliott' was the most vigorous cultivar late in the 2019 season, and 'Peruque' continued to exhibit the least vigor. Early in 2020, 'Elliott', 'Shoshoni', and 'VC1-68' were the most vigorous, and late in 2020 'Elliott' showed the greatest vigor, whereas 'Peruque' and 'Giles' had the lowest vigor ratings. Observed resistance to salt injury was related to seedling vigor more closely in late- than in early-season observations (Table 5).

'Elliott' stood out with the greatest growth each year and cumulatively throughout the course of the study (Fig. 1). All other cultivars grew at similar rates. More than $70 \%$ of 'Giles' seedlings died early during the study (Fig. 2). By June 2020, more than $70 \%$ of 'Shoshoni', 'Peruque', and 'VC1-68' had also died. 'Elliott', 'Ideal', and 'Riverside' had the lowest mortality rates. Between June and Oct. 2020, the greatest mortality occurred in 'Giles', which lost 3 of its 10 remaining trees. No other cultivars lost more than $10 \%$ of their remaining trees during this time. Averaged over the life of the study, tree

Table 6. Linear regression coefficients of determination between growth rates and tree survival, and resistance to salt injury and vigor ratings.

\begin{tabular}{lcc}
\hline & $\begin{array}{c}\text { Resistance to } \\
\text { salt injury } \\
\text { rating }\left(r^{2}\right)\end{array}$ & $\begin{array}{c}\text { Vigor } \\
\text { rating }\left(r^{2}\right)\end{array}$ \\
Variable & 0.410 & 0.565 \\
Tree growth & 0.530 & 0.390 \\
\hline
\end{tabular}


Table 7. Mean leaf nutrient concentrations measured in milligrams per kilogram and K:Na ratios on 9 Oct. 2019 and 6 Oct. 2020. ${ }^{\mathrm{z}}$

\begin{tabular}{|c|c|c|c|c|c|c|c|}
\hline Seed source cultivar & $\mathrm{P}$ & $\mathrm{Ca}$ & $\mathrm{Mg}$ & $\mathrm{Cl}$ & $\mathrm{Na}$ & K & $\mathrm{K}: \mathrm{Na}$ \\
\hline \multicolumn{8}{|l|}{2019} \\
\hline Elliott & $935 \mathrm{~d}$ & $11,725 \mathrm{ab}$ & $2,725 \mathrm{bc}$ & $3,258 \mathrm{ab}$ & $1,182 \mathrm{c}$ & 9,975 a & $10.1 \mathrm{a}$ \\
\hline Giles & $1,080 \mathrm{abc}$ & $10,750 \mathrm{~b}$ & $1,743 \mathrm{~d}$ & $2,913 \mathrm{~b}$ & $4,638 \mathrm{ab}$ & $7,050 \mathrm{~b}$ & $3.5 \mathrm{~b}$ \\
\hline Ideal & $1,078 \mathrm{abc}$ & $10,625 \mathrm{~b}$ & $3,353 \mathrm{~b}$ & $2,610 \mathrm{~b}$ & $3,393 \mathrm{bc}$ & $7,350 \mathrm{~b}$ & $2.3 \mathrm{~b}$ \\
\hline Peruque & 970 bcd & $9,450 \mathrm{~b}$ & $2,185 \mathrm{~cd}$ & $3,632 \mathrm{ab}$ & $5,570 \mathrm{ab}$ & $8,200 \mathrm{ab}$ & $1.5 \mathrm{~b}$ \\
\hline Riverside & $1,143 \mathrm{a}$ & $15,525 \mathrm{a}$ & $3,820 \mathrm{a}$ & $2,416 \mathrm{~b}$ & $3,485 \mathrm{bc}$ & $6,375 \mathrm{~b}$ & $1.9 \mathrm{~b}$ \\
\hline Shoshoni & $1,110 \mathrm{ab}$ & $12,250 \mathrm{ab}$ & $2,465 \mathrm{bcd}$ & $4,454 \mathrm{a}$ & $6,783 \mathrm{a}$ & $6,575 \mathrm{~b}$ & $1.1 \mathrm{~b}$ \\
\hline VC1-68 & $965 \mathrm{~cd}$ & $11,425 \mathrm{ab}$ & $2,525 \mathrm{bcd}$ & $2,727 \mathrm{~b}$ & $4,755 \mathrm{ab}$ & $6,475 \mathrm{~b}$ & $2.2 \mathrm{~b}$ \\
\hline \multicolumn{8}{|l|}{2020} \\
\hline Elliott & $911 \mathrm{c}$ & $7,974 \mathrm{~b}$ & $2,880 \mathrm{bc}$ & $4,637 \mathrm{bc}$ & $2,208 \mathrm{c}$ & $10,100 \mathrm{~b}$ & $14.5 \mathrm{a}$ \\
\hline Giles & $958 \mathrm{abc}$ & $8,333 \mathrm{~b}$ & $2,362 \mathrm{c}$ & $5,687 \mathrm{abc}$ & $3,266 \mathrm{bc}$ & $13,050 \mathrm{a}$ & $7.0 \mathrm{bc}$ \\
\hline Ideal & $1,090 \mathrm{a}$ & $8,717 \mathrm{~b}$ & $3,228 \mathrm{~b}$ & $3,174 \mathrm{c}$ & $4,869 \mathrm{~b}$ & $6,958 \mathrm{c}$ & $2.8 \mathrm{bc}$ \\
\hline Peruque & $977 \mathrm{abc}$ & $8,543 \mathrm{~b}$ & $2,434 \mathrm{c}$ & $7,640 \mathrm{a}$ & $4,834 \mathrm{~b}$ & $12,814 \mathrm{a}$ & $3.3 \mathrm{bc}$ \\
\hline Riverside & $942 \mathrm{bc}$ & $11,659 \mathrm{a}$ & $3,874 \mathrm{a}$ & $3,942 \mathrm{c}$ & $3,840 \mathrm{bc}$ & $7,294 \mathrm{c}$ & $3.3 \mathrm{bc}$ \\
\hline Shoshoni & $995 \mathrm{abc}$ & $8,317 \mathrm{~b}$ & $2,555 \mathrm{c}$ & $6,770 \mathrm{ab}$ & $8,624 \mathrm{a}$ & $6,342 \mathrm{c}$ & $0.9 \mathrm{c}$ \\
\hline VC1-68 & $1,059 \mathrm{ab}$ & $9,233 \mathrm{~b}$ & $2,783 \mathrm{bc}$ & $8,128 \mathrm{a}$ & $3,629 \mathrm{bc}$ & $10,533 \mathrm{ab}$ & $8.2 \mathrm{ab}$ \\
\hline
\end{tabular}

growth was related more strongly to ratings of tree vigor than to ratings of resistance to salt injury, whereas tree survival was related more closely to resistance to salt injury than plant vigor (Table 6). There was a very weak relationship $\left(r^{2}=0.136\right)$ between tree growth rate and survival (data not shown).

Cultivar differences in leaf $\mathrm{P}, \mathrm{Mg}, \mathrm{Ca}, \mathrm{Cl}$, $\mathrm{K}$, and $\mathrm{Na}$ concentrations were significant on 9 Oct. 2019 (Table 7). Other nutrients did not differ significantly among cultivars. Notably, 'Elliott' had a high $\mathrm{K}$ concentration and shared the lowest $\mathrm{Na}$ concentrations with 'Ideal' and 'Riverside'. 'Shoshoni' leaf Cl concentrations were higher than 'Ideal', 'Riverside', 'Giles', and 'VC1-68', but not 'Peruque' and 'Elliott'. The leaf K:Na ratio was much greater in 'Elliott' than in other cultivars.

Differences in $\mathrm{P}, \mathrm{Mg}, \mathrm{Ca}, \mathrm{Cl}, \mathrm{K}$, and $\mathrm{Na}$ concentrations were again significant among

$\mathbf{A}$
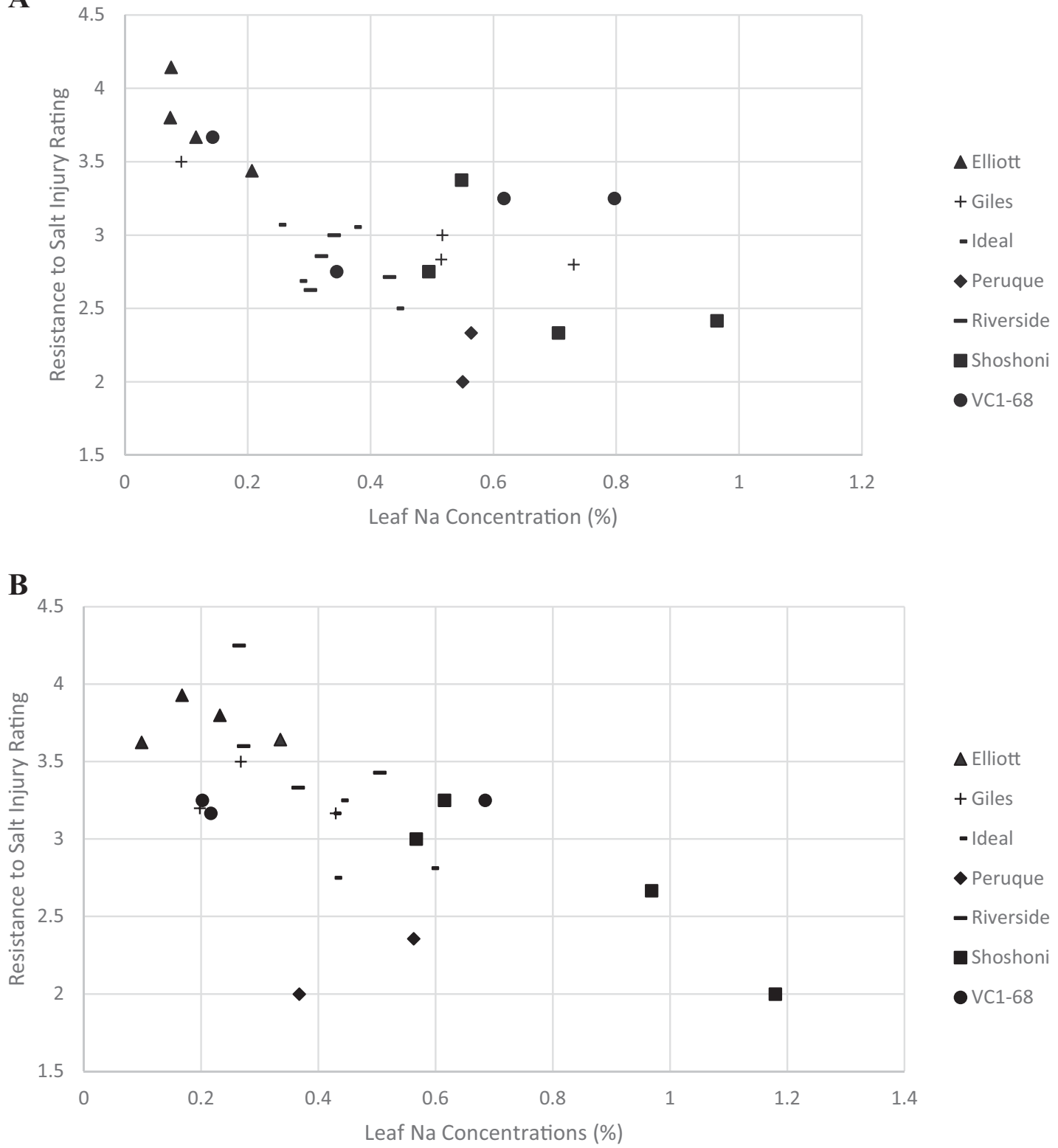

Fig. 3. Average resistance to salt injury ratings from composite samples and the corresponding Na percentages. (A) Samples collected 9 Oct. $2019\left(r^{2}=\right.$ $0.550)[y=-0.523 \times \ln (x)+2.43]$. (B) Samples collected 6 Oct. $2020\left(r^{2}=0.412\right)(y=-1.39 x+3.79)$. 
Table 8. Regression coefficients of determination $\left(r^{2}\right.$ values) between resistance to salt injury, vigor, and growth, and nutrient concentrations of leaves sampled in 2019 and 2020.

\begin{tabular}{lccc}
\hline Variable & Leaf nutrient & 2019 & 2020 \\
\hline Resistance & $\mathrm{Na}$ & $0.550^{* *}$ & $0.412^{* *}$ \\
to salt & $\mathrm{K}$ & $0.168^{*}$ & $\mathrm{NS}$ \\
injury & $\mathrm{Cl}$ & $\mathrm{NS}$ & $0.210^{*}$ \\
& $\mathrm{~K}: \mathrm{Na}$ & $0.545^{* *}$ & $0.365^{* *}$ \\
Vigor & $\mathrm{Na}$ & $0.586^{* *}$ & $\mathrm{NS}$ \\
& $\mathrm{K}$ & $0.198^{*}$ & $\mathrm{NS}$ \\
& $\mathrm{Cl}$ & $\mathrm{NS}$ & $\mathrm{NS}$ \\
& $\mathrm{K}: \mathrm{Na}$ & $0.500^{* *}$ & $0.231^{*}$ \\
Growth & $\mathrm{Na}$ & $0.321^{* *}$ & $\mathrm{NS}$ \\
& $\mathrm{K}$ & $0.198^{*}$ & $\mathrm{NS}$ \\
& $\mathrm{Cl}$ & $\mathrm{NS}$ & $\mathrm{NS}$ \\
& $\mathrm{K}: \mathrm{Na}$ & $0.545^{* *}$ & $0.370^{* *}$
\end{tabular}

NS, *, **Nonsignificant or significant at $P>\mathrm{F}=$ 0.05 , highly significant at $P>\mathrm{F}=0.01$. cultivars on 6 Oct. 2020 (Table 7). Notably, 'Elliott' shared the lowest $\mathrm{Na}$ concentration with 'Giles', 'VC1-68', and 'Riverside'. Although 'Peruque', 'Giles', and 'VC1-68' had the highest $\mathrm{K}$ concentrations, 'Elliott' had the greatest $\mathrm{K}: \mathrm{Na}$ ratio (although not significantly greater than ' $\mathrm{VC} 1-68$ ').

There was a linear relationship between leaf $\mathrm{Na}$ concentration and resistance to salt injury in $2019\left(r^{2}=0.550\right)$ (Fig. 3A, Table $8)$, and between leaf $\mathrm{K}$ concentration and resistance to salt injury $\left(r^{2}=0.168\right)$, but the relationship between leaf $\mathrm{Cl}$ concentration and resistance to salt injury was not significant (Table 8). There was also a linear relationship between leaf $\mathrm{Na}$ and resistance to salt injury in $2020\left(r^{2}=0.412\right)$ (Fig. 3B, Table 8 ), and the relationship of resistance to salt injury with $\mathrm{Cl}$ had an $r^{2}$ value of 0.210 , whereas $\mathrm{K}$ and resistance to salt injury were not significantly related (Table 8 ). The relationship of resistance to salt injury with leaf $\mathrm{K}: \mathrm{Na}$ ratio $\left(r^{2}=0.545\right)$ (Fig. 4A, Table 8) was nearly as strong as that of $\mathrm{Na}$ concentrations alone in 2019. In 2020, the relationship of the $\mathrm{K}: \mathrm{Na}$ ratio with resistance to salt injury was slightly weaker $\left(r^{2}=0.365\right)$ than the relationship of $\mathrm{Na}$ alone (Fig. 4B, Table 8).

The leaf $\mathrm{K}: \mathrm{Na}$ ratio was also related to cumulative growth in trunk diameter in 2019 $\left(r^{2}=0.545\right)$ (Fig. 5A, Table 8). In 2020, the correlation between increases in trunk circumference and K:Na ratio was weaker $\left(r^{2}=\right.$ 0.370 ) than in 2019 (Fig. 5B, Table 8). Notably, 'Elliott' had the greatest $\mathrm{K}: \mathrm{Na}$ ratio in
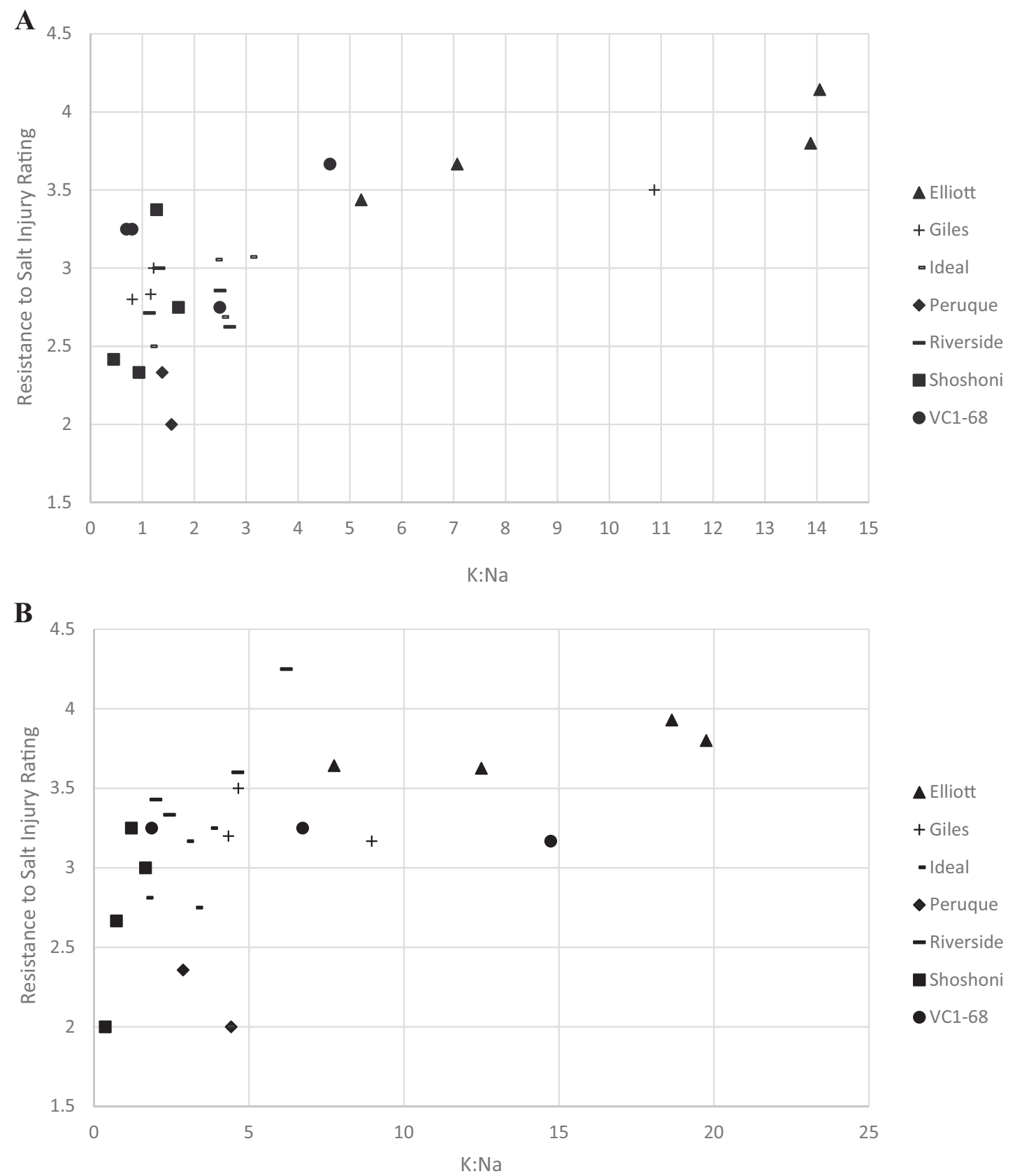

Fig. 4. Average resistance to salt injury ratings from composite samples and the corresponding K:Na ratios. (A) Samples collected 9 Oct. $2019\left(r^{2}=0.545\right)$ $(y=0.0975 x+2.67)$. (B) Samples collected 6 Oct. $2020\left(r^{2}=0.365\right)[y=0.336 \times \ln (x)+2.74]$. 

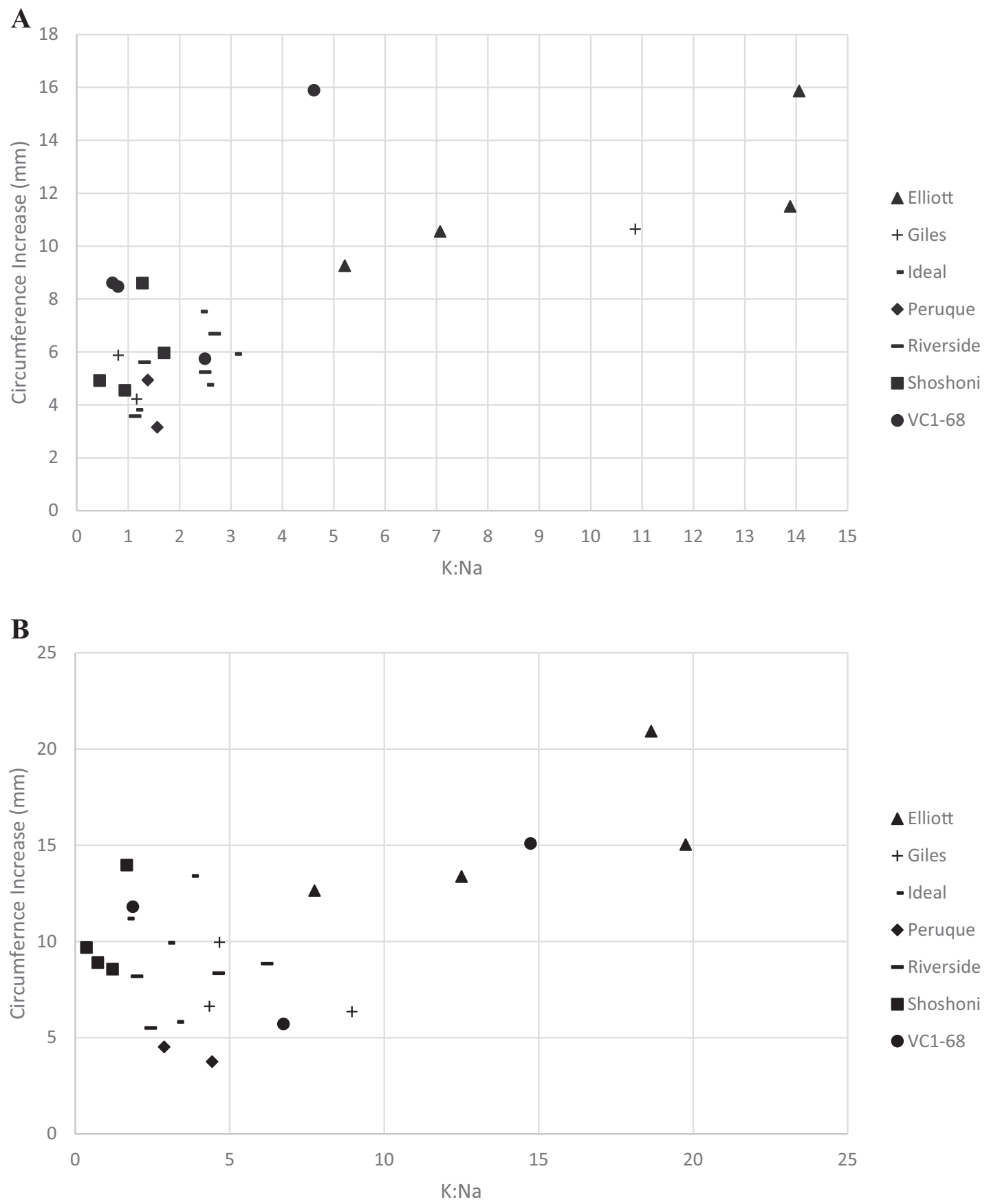

Fig. 5. Average trunk circumference increases of trees in composite samples and the corresponding K:Na ratios. (A) Samples collected 9 Oct. $2019\left(r^{2}=\right.$ $0.545)(y=0.651 x+5.04)$. (B) Samples collected 6 Oct. $2020\left(r^{2}=0.370\right)(y=0.454 x+7.31)$.

2019 and exhibited the greatest growth. 'Elliott' again had the greatest K:Na ratio in 2020, but was not statistically different from 'VC1-68'.

\section{Discussion}

Overall, 'Elliott' ratings for both vigor and resistance to salt injury were either better than, or among the best of all cultivars. 'Elliott' growth rate, measured by trunk diameter increase, exceeded that of other cultivars throughout the experiment, and it was among the cultivars with the lowest mortality. 'Elliott' was also among the cultivars with the lowest leaf $\mathrm{Na}$ and highest leaf $\mathrm{K}$ concentrations, and had the greatest leaf $\mathrm{K}: \mathrm{Na}$ ratios (nearly 3-fold greater than any other cultivar in 2019).

The correlation between the $\mathrm{K}: \mathrm{Na}$ ratio and resistance to salt injury supports previous reports of the importance of the K:Na ratio in salt stress tolerance for a range of other plant species (Gorham, 1990; Munns and Tester, 2008; Wakeel, 2013). Our results show an increased resistance to salt injury at a $\mathrm{K}: \mathrm{Na}$ ratio between about four and six. Further research is needed to confirm this threshold. This knowledge may be beneficial in rootstock evaluation and selection, and in the diagnosis of salinity issues in mature, grafted pecan orchards.
Because 'Elliott' maintained high leaf $\mathrm{K}$ and was also among the cultivars lowest in leaf $\mathrm{Na}$ concentration, we could not specifically attribute the observed tolerance to one of these elements. Our results conform to the findings of Miyamoto et al. (1985), in which the 'Riverside' cultivar accumulated the least amount of $\mathrm{Na}$ and displayed the least effect of salt on measured growth parameters relative to 'Apache' and 'Burkett', the other cultivars studied. Miyamoto et al. (1985) did not report leaf $\mathrm{K}$ concentrations.

In our study, leaf $\mathrm{Cl}$ concentrations in Oct. 2019 did not reach levels previously reported to cause leaf necrosis in pecans, perhaps explaining the lack of correlation with 
resistance to salt injury, vigor, or growth. The highest leaf $\mathrm{Cl}$ concentrations were 3258 to $4454 \mathrm{mg} \cdot \mathrm{kg}^{-1}$, found in 'Shoshoni', 'Elliott', and 'Peruque', whereas previously reported leaf $\mathrm{Cl}$ concentrations required for necrosis in pecan leaves are 5000 to $6000 \mathrm{mg} \cdot \mathrm{kg}^{-1}$ (Faruque, 1968; Harper, 1946). Chloride concentrations in Oct. 2020 were greater in all cultivars than in 2019. Four cultivars ('Giles', 'Peruque', 'Shoshoni', and 'VC1-68') exceeded $5000 \mathrm{mg} \cdot \mathrm{kg}^{-1}$. Even with this increase in $\mathrm{Cl}$ concentrations, the correlation between leaf $\mathrm{Cl}$ and resistance to salt injury was weaker than that of $\mathrm{Na}$. This result supports the finding of Miyamoto et al. (1985) that $\mathrm{Na}$, rather than $\mathrm{Cl}$, is more closely related to the degree of salinity injury in pecans.

Although the physiological mechanisms for differences in salt tolerance among cultivars are not well-understood, it is clear that the variation of performance is controlled genetically, which highlights the potential for rootstock improvement. Because all seeds were from open-pollinated seed sources, we do not know the paternal contribution. The results of this experiment give evidence of the heavy influence of the maternal parent in seedstock tolerance to saline-sodic conditions. The likely Mexican ancestry of 'Elliott' may be an explanation of its genetic salt tolerance adaptations and superior performance to cultivars chosen from other geographic regions. The significant relationships between leaf $\mathrm{Na}$ concentration and $\mathrm{K}: \mathrm{Na}$ ratio, and the observed resistance to salt injury and tree growth rate suggest that these measures could be used to predict genotype salt tolerance in short-term evaluations.

\section{Literature Cited}

Almeida, D.M., M.M. Oliveira, and N.J.M. Saibo. 2017. Regulation of $\mathrm{Na}+$ and $\mathrm{K}+$ homeostasis in plants: Towards improved salt stress tolerance in crop plants. Genet. Mol. Biol. 40(1):326-345, doi: https://doi.org/10.1590/1678-4685-GMB2016-0106.

Cakmak, I. 2000. Possible roles of zinc in protecting plant cells from damage by reactive oxygen species. New Phytol. 146(2):185-205.

Deb, S.K., P. Sharma, M.K. Shukla, and T.W. Sammis. 2013. Drip-irrigated pecan seedlings response to irrigation water salinity. HortScience 48:1545-1548.

Faruque, A. H. M. 1968. The effect of salinity on phytotoxicity and ion uptake of pecan seedlings (Carya illinoensis wag, cv. Riverside). Texas A\&M University, College Station, TX, PhD Diss.

Gorham, J. 1990. Salt tolerance in the Triticeae: $\mathrm{K} / \mathrm{Na}$ discrimination in Aegilops species. J. Expt. Bot. 41(226):615-621.

Grauke, L.J. 2010. Pecan seed stock selection: Regional implications. Proceedings 2010 Southeastern Pecan Growers Association.

Grauke, L.J. and T.E. Thompson. 2019. Pecan breeding and genetics. Agricultural Research Service, U.S. Department of Agriculture. 18 Dec. 2019. <https://cgru.usda.gov/carya/pecans/ cvintro.htm $>$.

Gupta, V.K. and S.P. Gupta. 1984. Effect of zinc sources and levels on the growth and Zn nutrition of soybean (Glycine max. L.) in the presence of chloride and sulphate salinity. Plant Soil 81(2):299-304.

Hanna, J.D. 1972. Absorption and accumulation of chloride ions by pecan (Carya illinoensis $\mathrm{KOCH}$ ) seedling rootstocks. Texas A\&M University, College Station, TX. PhD Diss.

Harper, H.J. 1946. Effect of Cl on physical appearance and chemical composition of leaves on pecans and other native trees of Oklahoma. Tech. Bul.

Heerema, R.J. 2013. Diagnosing nutrient disorders of New Mexico pecan trees. New Mexico State University Guide H-658, College of Agricultural, Consumer and Environmental Sciences, New Mexico State University, Las Cruces, NM.

Miyamoto, S., G.R. Gobran, and K. Piela. 1985. Salt effects on seedling growth and ion uptake of three pecan rootstock cultivars. Agron. J. 77:383-388.

Miyamoto, S., T. Riley, G. Gobran, and J. Petticrew. 1986. Effects of saline water irrigation on soil salinity, pecan tree growth and nut production. Irr. Sci. 7:83-95.

Miyamoto, S. and J.B. Storey. 1995. Soil management in irrigated pecan orchards in the southwestern United States. HortTechnology 5:219-222.

Munns, R. and M. Tester. 2008. Mechanisms of salinity tolerance. Annu. Rev. Plant Biol. 59: 651-681, doi: https://doi.org/10.1146/annurev. arplant.59.032607.092911.

Norvell, A.W. and R.M. Welch. 1993. Growth and nutrient uptake by barley (Hordeum vulgare $\mathrm{L}$. cv. Herta): Studies using an N-(2hydroxyethyl) ethylenedinitrilotriacetic acid-buered nutrient solution technique: I. Zinc ion requirements. Plant Physiol. 101:619-625.

Post, D.F., D.M. Hendricks, and J.M. Hart. 1977. Soils of the University of Arizona Experiment Station: Safford. Agricultural Engineering and Soil Science 77-1 Report, University of Arizona.

Rajendran, K., M. Tester, and S.J. Roy. 2009. Quantifying the three main components of salinity tolerance in cereals. Plant Cell Environ. 32(3):237-249, doi: https://doi.org/10.1111/ j.1365-3040.2008.01916.

Saxena, A.K. and R.B. Rewari. 1990. Influence of zinc on nodulation and ion uptake by chickpea under saline conditions. J. Indian Soc. Soil Sci. 38(2):363-364.

Sumner, M.E. 1993. Sodic soils: New perspectives. Austral. J. Soil Res. 31(6):683-750.

Tuteja, N. 2007. Mechanisms of high salinity tolerance in plants. Methods Enzymol. 428:419-438, doi: https://doi.org/10.1016/S0076-6879(07)28024-3.

Your Weather Service. 2021. U.S. climate data. 18 Dec. 2020. <https://www.usclimatedata.com/ climate/safford/arizona/united-states/usaz0193>.

Wakeel, A. 2013. Potassium-sodium interactions in soil and plant under saline-sodic conditions. J. Plant Nutr. Soil Sci. 176(3):344-354, doi: https://doi.org/10.1002/jpln.201200417.

Warrence, J.N., J.W. Bander, and K.E. Pearson. 2002. Basics of salinity and sodicity effects on soil physical properties. Department of Land Resources and Environmental Sciences, Montana State University, Bozeman, MT.

Zhang, H., J.L. Schroder, J.J. Pitman, J.J. Wang, and M.E. Payton. 2005. Soil salinity using saturated paste and 1:1 soil to water extracts. Soil Sci. Soc. Amer. J. 69:1146-1151, doi: https:// doi.org/10.2136/sssaj2004.0267. 